\title{
Pengaruh Penambahan Ekstrak Touge Sebagai Sumber Nitrogen Alternatif Pada Pembuatan Nata De Salacca
}

\author{
The Effect Of Addition Of Touge Extract As A Source Of Alternative Nitrogen \\ For Making Nata De Salacca
}

\author{
Yusnita Wahyuni Silitonga*, Rini Hayati Lubis \\ Departemen Agroteknologi Fakultas Pertanian, Universitas Muhammadiyah Tapanuli Selatan \\ Jl. Sutan Muhammad Arif No. 32 Padangsidimpuan, Indonesia \\ *Email: yusnita.wahyuni@um-tapsel.ac.id
}

\begin{abstract}
ABSTRAK
Aplikasi bioteknologi dapat digunakan untuk meningkatkan nilai ekonomis salak. Salah satu jenis olahan salak dengan memanfaatkan mikroba melalui pendekatan bioteknologi adalah nata de salacca. Proses pembentukan nata memanfaatkan pupuk zwavelzure ammonia (ZA) sebagai sumber nitrogen yang relatif berbahaya jika dikonsumsi dalam jumlah melebihi standar pemakaian. Penelitian ini bertujuan untuk mengetahui pengaruh penambahan ekstrak kecambah kacang hijau (touge) pada kualitas nata de salacca. Konsentrasi ekstrak toge yang digunakan pada penelitian ini adalah 0\%, 1\%, 2\%, 3\%. Pengamat yang dilakukan adalah pengamatan fisik seperti ketebalan, bobot dan rendemen. Penambahan ekstrak touge $1 \%$ menghasilkan bobot nata sebesar $381,6 \mathrm{~g}$ dan tebal $0,53 \mathrm{~cm}$. Penambahan ekstrak touge 3\% menghasilkan bobot nata 438,6 g dan tebal 0,57 cm. Semakin tinggi jumlah ekstrak touge yang ditambahkan maka bobot dan ketebalan nata de salacca yang dihasilkan semakin tinggi.
\end{abstract}

Kata Kunci: Nata De Salacca, Pupuk ZA, Salak, Touge

\begin{abstract}
The application of biotechnology can be used to improve salak economic value. One of salak processed type use microbes by implementation of biotechnology is nata de salacca. The establishment of nata de salacca use of zwavelzure ammonia (ZA) that was alternative nitrogen source relatively dangerous if consumed in quantity more than standard discharging. The objective of this research was to know the effect of touge extract addition on nata de salacca produce. Completely randomized design was applied in this research with three replications. The concentration of touge extract used in this research is $0 \%, 1 \%, 2 \%, 3 \%$. The observer conducted by physical observation such as weight, thickness and rendement of nata. The addition of $1 \%$ touge extract produce 381,6 $\mathrm{g}$ of weight and 0,53 cm of thickness. The addition of $3 \%$ touge extract produce 438,6 g of weight and 0,57 $\mathrm{cm}$ of thickness. The higher number of touge extrack added so weights and thickness of the nata produse is higher.
\end{abstract}

Keywords: Nata De salacca, Salak, Touge, ZA Fertilizer

\section{A. PENDAHULUAN}

Salak Sidimpuan (Salacca sumatrana Becc) merupakan komoditas lokal daerah Padangsidimpuan dan Tapanuli Selatan. Luas pertanaman salak sekitar 13.924 Ha dengan produksi 236.793 ton/tahun (Dinas Pertanian dan Ketahanan Pangan Kabupaten Tapanuli Selatan, 2010). Sebagian besar salak sidimpuan hanya dijual dan dikonsumsi dalam bentuk 
segar padahal salak tanpa melalui proses pengolahan memiliki nilai ekonomis yang rendah.

Aplikasi bioteknologi dapat digunakan untuk meningkatkan nilai ekonomis salak. Salah satu jenis olahan salak dengan memanfaatkan mikroba melalui pendekatan bioteknologi adalah nata de salacca (Pratiwi et al, 2015). Pengolahan menjadi nata de salacca mungkin bisa dilakukan karna salak mengandung nutrisi yang dibutuhkan Acetobacter xylinum untuk aktivitas metabolismenya (Nadyah et al, 2005).

Nata dapat terbentuk apabila dalam media mengandung nutrisi yang cukup untuk pertumbuhan A. xylinum. Salah satu nutrisi yang penting adalah asupan nitrogen (Fifendi et al, 2011). Selama ini sumber nitrogen yang banyak dipakai adalah pupuk zwavelzure ammonia (ZA) yang relatif berbahaya jika dikonsumsi dalam jumlah melebihi standar pemakaian. Saat ini telah berkembang ZA yang memenuhi persyaratan mutu pangan, namun harganya jauh lebih mahal dibanding pupuk ZA yang dipakai untuk memupuk tanaman (Arifiani et al, 2015).

Kacang-kacangan merupakan sumber protein yang tinggi. Pemanfaatan kacangkacangan misalnya kecambah kacang hijau sebagai sumber nitrogen alternatif pada pembuatan nata dapat menjadi salah satu upaya yang dapat dilakukan untuk menyelesaikan penggunaan pupuk ZA pada pembuatan nata. Penelitian ini bertujuan untuk mengetahui pengaruh penambahan ekstrak kecambah kacang hijau (touge) pada kualitas nata de salacca.

\section{B. METODOLOGI}

\section{Bahan dan Alat}

Bahan yang digunakan adalah salak, touge, air, cuka, gula pasir, pupuk ZA, stater Acetobacter xylinum.

Alat yang digunakan pada penelitian ini adalah blender, baki, saringan, dandang, ph meter, gelas ukur, timbangan, pisau, kompor, kertas koran.

\section{Rancangan Penelitian}

Penelitian ini menggunakan Rancangan Acak Lengkap (RAL) dengan 4 perlakuan dan 3 ulangan, perlakuan yang digunakan adalah beberapa variasi konsentrasi ekstrak touge yaitu $0 \%, 1 \%, 2 \%, 3 \%$. Data hasil pengamatan dianalisis secara sidik ragam dengan uji $\mathrm{F}$, jika $\mathrm{F}$ hitung perlakuan lebih besar dari $\mathrm{F}$ tabel 5\% dilanjutkan dengan uji lanjut Tukey.

\section{Teknik Pengumpulan Data}

Teknik pengumpulan data berdasarkan data primer yaitu data sumber yang pertama yang secara teknis dalam penelitian, misalnya ketebalan nata tiap perlakuan, bobot nata tiap perlakuan serta rendemen pada tiap perlakuan. Rendemen nata diukur dengan metode gravimetri. Nata yang telah dipanen ditimbang dengan timbangan analitik, berat tersebut dinyatakan sebagai berat fermentasi (AOAC, 2007).

$$
\text { Rendemen }=\frac{\text { berat fermentasi }}{\text { berat total medium cair yang digunakan }}
$$

\section{Pelaksanaan Penelitian}

\section{Ekstraksi buah salak}

Buah salak dipisahkan dari kulit dan bijinya kemudian dibersihkan. Daging buah salak dipotong kecil-kecil. Daging salak yang sudah dipotong dimasukkan ke dalam air yang telah dimasak dengan perbandingan $1: 4$ (1 kg buah salak dalam 4 liter air) kemudian diblender sampai halus. Setelah itu, jus buah disaring untuk mendapatkan sari buahnya dan ampas buah dibuang. Sari buah tersebut digunakan sebagai bahan pembuatan nata.

\section{Ekstraksi Touge}

Touge dengan jumlah $1000 \mathrm{~g}$ dicuci bersih dan dihancurkan dengan blender. Touge yang telah halus direbus dengan air sebanyak 1000 $\mathrm{ml}$, setelah mendidih ekstrak touge disimpan di dalam botol steril dan tertutup. Perlakuan yang dicoba terdiri dari:

1. Konsentari ekstak toge $0 \%$ (sumber nitrogen ZA)

2. Konsentari ekstak toge $1 \%$

3. Konsentari ekstak toge $2 \%$

4. Konsentari ekstak toge $3 \%$

\section{Pembuatan Nata de Salacca}

Sari buah salak direbus sampai mendidih lalu ditambahkan dengan $5 \%$ gula pasir (50 gram gula dalam 1 liter air), ekstrak touge sesuai konsentrasi masing-masing perlakuan. perlakuan yang digunakan dalam penelitian ini 
adalah dengan penambahan ekstrak touge dalam jumlah yang bervariasi yaitu $10 \mathrm{ml}, 20 \mathrm{ml}$ dan $30 \mathrm{ml}$ dalam $1000 \mathrm{ml}$ ekstrak sari buah salak. Untuk menyesuaikan $\mathrm{pH}$ larutan (4-5) ditambahkan Asam cuka dapur. Setelah mendidih larutan sari buah dituang ke dalam nampan bersih sebanyak kurang lebih 1 liter kemudian ditutup rapat dengan koran bersih. Selanjutnya, larutan dibiarkan selama 1 hari dan siap digunakan sebagai substrat.

Inokulum $A$. xylinum dituang ke dalam substrat sebanyak 20\% dengan menjaga tutup kertas agar tidak terbuka lebar (meminimalkan kontaminasi). Selanjutnya, bakteri diinkubasi selama 7-10 hari di tempat yang rata, tahan goncangan, dan bersuhu ruangan. Setelah 7-10 hari, nata siap dipanen.

\section{HASIL DAN PEMBAHASAN}

Sumber nirogen merupakan faktor penting dalam pembuatan nata. Nitrogen diperlukan dalam pembentukan protein yang penting bagi pertumbuhan sel dan pembentukan enzim pada bakteri. Kekurangan nitrogen dapat menghambat pembentukan enzim sehingga proses fermentasi menjadi tidak sempurna (Arifiani et al, 2015).

Tabel 1 menunjukkan bahwa penambahan konsentrasi ekstrak touge yang semakin meningkat dari 1\% - 3\% dapat meningkatkan ketebalan nata. Menurut Naufalin dan Wibowo (2003) peningkatan ketebalan nata berkaitan dengan ketersedian nutrisi dalam media fermentasi. Kualitas nata dipengaruhi oleh pertumbuhan bakteri Acetobacter xylinum, untuk merangsang pertumbuhan bakteri tersebut dibutuhan sumber nitrogen yang memadai baik yang berasal dari bahan organik maupun anorganik (Fifendi et al, 2011).

Tabel 1 Pengaruh Konsentrasi Ektrak Touge tehadap Bobot dan ketebalan Nata

\begin{tabular}{cccc}
\hline No & $\begin{array}{c}\text { Penambahan } \\
\text { Ekstrak Touge }\end{array}$ & Bobot $(\mathrm{g})$ & Tebal $(\mathrm{cm})$ \\
\hline 1 & $0(\mathrm{ZA})$ & $473,6 \mathrm{a}$ & 0,60 \\
2 & $1 \%$ & $381,6 \mathrm{a}$ & 0,53 \\
3 & $2 \%$ & $434,3 \mathrm{a}$ & 0,53 \\
4 & $3 \%$ & $438,6 \mathrm{a}$ & 0,57 \\
\hline
\end{tabular}

Ket: Bobot: angka-angka yang diikuti huruf kecil yang sama berbeda tidak nyata setelah uji lanjut tukey

Tebal: berbeda tidak nyata menurut uji $F$

Ketersediaan nitrogen yang cukup dapat memicu aktivitas bakteri dalam proses pembentukan nata. Ketebalan nata berbanding lurus dengan bobot nata, jika nata yang terbentuk tebal maka maka bobot yang diperoleh juga tinggi (Arifiani et al, 2015). Pada tabel 1 tadap dilihat bahwa perlakuan 2 (konsentrasi ekstrak touge 1\%) menunjukkan bobot dan ketebalan nata de salacca yang terbentuk paling rendah yaitu 381,6 g dan tebal $0,53 \mathrm{~cm}$. Pada perlakuan 4 (konsetrasi ekstrak touge $3 \%$ ) bobot nata yang terbentuk adalah 438,6 g dan tebal 0,57 cm. Hal ini menunjukkan bahwa metabolisme A. xylinum bekerja dengan baik dalam pembentukan nata.

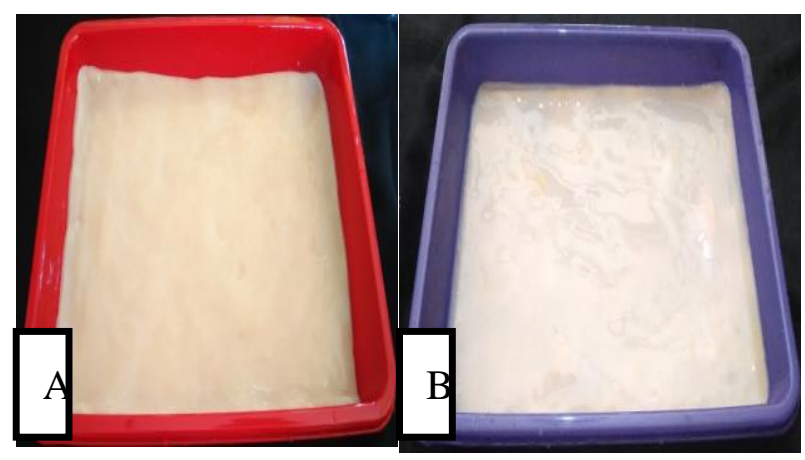

Gambar 1 Perbandingan konsentrasi ekstrak touge pada pembuatan nata de salacca A. 1\%, B. 3\%

Selain sumber nitrogen ketebalan nata yang terbentuk juga dipengaruhi oleh konsentrasi gula, luas permukaan fermentasi dan lama fermentasi. Nata yang terbentuk akan semakin tebal jika luas wadah medium fermentasi semakin luas, karena suplai oksigen pada wadah yang demikian lebih banyak dibandingkan dengan wadah yang sempit (Hakim dan Setiawan, 2014).

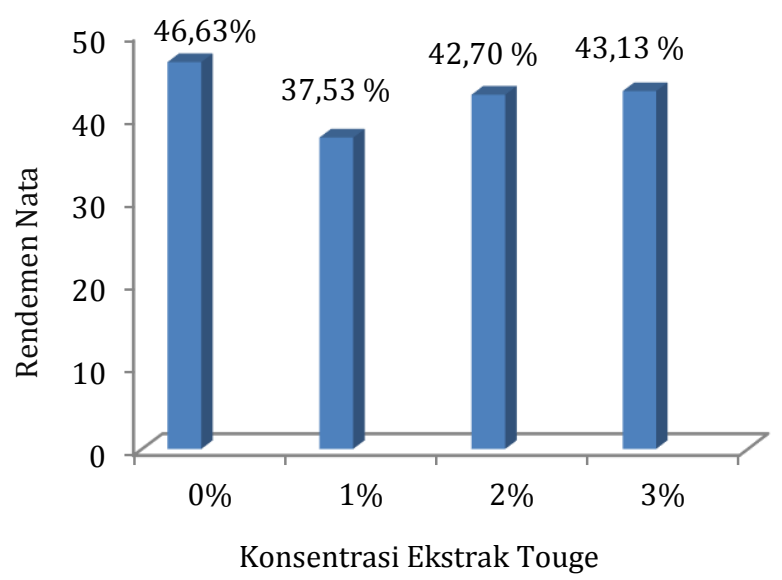

Gambar 2 Rendemen nata de salacca yang dihasilkan dengan penembahan beberapa konsentrasi ekstrak touge 
Gambar 2 menunjukkan bahwa semakin tinggi konsentrasi ekstrak toge yang digunakan maka rendemen yang dihasilkan semakin tinggi. Penambahan sumber nitrogen ke mediun fermentasi nata tidak hanya mencukupi energi yang dibutuhkan A. xylinum, tetapi juga merangsang pembentukan selulosa nata yang tebal. Jika selulosa yang yang terbentuk semakin meningkat maka serat yang terbentuk juga semakin banyak, sehingga rendemen yang terukur juga semakin tinggi (Naufalin dan Wibowo, 2003).

Pada penelitian Lempang (2006) rendeman nata yang dihasilkan dapat mencapai $80-93 \%$. Rendemen yang dihasilkan tinggi jika nutrisi yang dibutuhkan $A$. xylinum tercukupi dan jumlah inokulan A. xylinum yang ditambahkan pada substrat tidak kurang dari jumlah substrat yang tersedia. Selain faktor tersebut hal yang mempengaruhi tinggi rendahnya rendemen yang dihasilakan adalah lama fermentasi, makin lama umur panen maka rendemen yang dihasilkan semakin tinggi.

\section{KESIMPULAN}

Penambahan konsentrasi ekstrak touge 3\% mengahasilkan karakter nata de salacca terbaik baik bobot, ketebalan dan rendemen. Semakin tinggi jumlah ekstrak touge yang ditambahkan maka bobot, ketebalan dan rendemen nata de salacca yang dihasilkan semakin tinggi.

\section{UCAPAN TERIMAKASIH}

Ucapan terima kasih kepada APB Universitas Muhammadiyah Tapanuli Selatan yang telah memberi Hibah Penelitian Internal Dosen Pemula tahun 2018.

\section{DAFTAR PUSTAKA}

AOAC. International. 2007. Official Methods of Analysis, $18^{\text {th }}$ edn. AOAC International. Gaithersburg. MD

Arifiani N, Sani TA, Utami AS. 2015. Peningkatan Kualitas Nata De Cane dari Limbah Nira Tebu Metode Budchips dengan Penambahan Ekstrak Touge sebagai Sumber Nitrogen. Bioteknologi. 12(2): 2932.

Dinas Pertanian dan Ketahanan Pangan Kabupaten Tapanuli Selatan. 2010.

Fifendi M. Dwi H.P. Sinta S.M. 2011. Pengaruh Penambahan Ektrak Kecambah Touge sebagai Sumber Nitrogen terhadap Mutu Nata De Kakao. Jurnal Sainstek. 3 (2): 165170.

Hakim, L, Setiawan B.H. 2014. Pemanfaatan Salak Afkir sebagai Media Produksi Nata de salacca di Kabupaten Banjarnegara. Media Agrosains. 1 (1): 1-4.

Lempang M. 2006. Rendemen dan Kandungan Nutrisi Nata De Pinnata yang Diolah dari Nira Aren. Skripsi. Universitas Hasanuddin, Makassar.

Nadiyah, Krisdiyanto, Aulia A. 2005. Kemampuan Bakteri Acetobacter Cylinum Mengubah Karbohisrat Pada Limbah Padi (Bekatul) Menjadi Selulosa. Bioscientiae. 2 (2):37-47.

Naufalin R dan Wibowo C. 2003. Pengaruh Penambahan Sukrosa dan Ekstrak Kecambah pada Kualitas Nata De Cassava. Jurnal Pembangunan Pedesaan. 3 (1): 4956.

Pratiwi, R. Lestari F.B. Widiyanto, D. 2015. Pemanfaatan Limbah Buah Salak Pondoh sebagai Substrat Nata De Salacca melalui Aplikasi Bioteknologi Dusun Tegal Domban, Sleman, Yogyakarta. Indonesian Jurnal of Community Engagement. 1(1): 39-50. 